\title{
Differential expression of E-cadherin at the surface of rat $\beta$-cells as a marker of functional heterogeneity
}

\author{
Domenico Bosco, Dominique G Rouiller ${ }^{1}$ and Philippe A Halban ${ }^{2}$ \\ Surgical Research Unit, Department of Surgery, Cell Isolation and Transplantation Center, CMU, Geneva University Hospitals, 1, rue Michel-Servet, 1211 \\ Geneva-4, Switzerland \\ ${ }^{1}$ Division of Endocrinology, Diabetes and Nutrition, Geneva University Hospitals, 1211 Geneva-14, Switzerland \\ ${ }^{2}$ Department of Genetic Medicine and Development, University Medical Center, 1211 Geneva-4, Switzerland \\ (Requests for offprints should be addressed to D Bosco; Email: domenico.bosco@medecine.unige.ch)
}

\begin{abstract}
The aim of this study was to assess whether the expression of E-cadherin at the surface of rat $\beta$-cells is regulated by insulin secretagogues and correlates with insulin secretion. When cultured under standard conditions, virtually all $\beta$-cells expressed E-cadherin observed by immunofluorescence, but heterogeneous staining was observed. Using fluorescence-activated cell sorting (FACS), two $\beta$-cell sub-populations were sorted: one that was poorly labeled ('ECad-low') and another that was highly labeled ('ECad-high'). After 1-h stimulation with $16.7 \mathrm{mM}$ glucose, insulin secretion (reverse hemolytic plaque assay) from individual ECad-high $\beta$-cells was higher than that from ECad-low $\beta$-cells. $\mathrm{Ca}^{2+}$-dependent $\beta$-cell aggregation was increased at $16.7 \mathrm{mM}$ glucose when compared with $2.8 \mathrm{mM}$ glucose. E-cadherin at the surface of $\beta$-cells was increased after $18 \mathrm{~h}$ at 11.1 and $22.2 \mathrm{mM}$ glucose when
\end{abstract}

compared with $2 \cdot 8 \mathrm{mM}$ glucose, with the greatest increase at $22 \cdot 2 \mathrm{mM}$ glucose $+0.5 \mathrm{mM}$ isobutylmethylxanthine (IBMX). While no labeling was detected on freshly trypsinized cells, the proportion of stained cells increased in a time-dependent manner during culture for 1,3 , and $24 \mathrm{~h}$. This recovery was faster when cells were incubated at 16.7 vs $2.8 \mathrm{mM}$ glucose. Cycloheximide inhibited expression of E-cadherin at $2.8 \mathrm{mM}$ glucose, but not at $16.7 \mathrm{mM}$, while depolymerization of actin by either cytochasin B or latrunculin B increased surface Ecadherin at low glucose. In conclusion, these results show that expression of E-cadherin at the surface of islet $\beta$-cells is controlled by secretagogues including glucose, correlates with insulin secretion, and can serve as a surface marker of $\beta$-cell function.

Journal of Endocrinology (2007) 194, 21-29

\section{Introduction}

E-cadherin is a calcium-dependent transmembrane protein involved in homotypic cell-cell interactions (Angst et al. 2001). It is a member of the cadherin superfamily that is mainly expressed in the epithelial cells of many tissues, including endocrine pancreas (Rouiller et al. 1991). This adhesive molecule allows neighboring cells to stick together, but more interestingly, it is also involved in the regulation of signaling events (Ozawa \& Kemler 1992, Aberle et al. 1996). The distal cytoplasmic domain of E-cadherin is bound to intracellular proteins known as catenins that serve to link the complex to the actin cytoskeleton (Ozawa \& Kemler 1992, Aberle et al. 1996), to other proteins involved in signal transduction, and to nuclear transcription factors (Behrens et al. 1996). Thus, E-cadherin has been shown to play a central role in the development and maintenance of epithelial morphology, cell differentiation, migration proliferation, and apoptosis.

In the endocrine pancreas, adhesion molecules have been thought to be responsible for segregation during histogenesis of the different types of insular cells (Rouiller et al. 1990).
By interfering with endogenous cadherin activity in $\beta$-cells during pancreatic development, the initial clustering of $\beta$-cells and the normal localization of glucagon-producing $\alpha$-cells in the periphery of pancreatic islets, which normally begins at E13.5-E14.5 days, were perturbed (Dahl et al. 1996, Esni et al. 1999). In addition, the loss of E-cadherin expression coincides with the transition from well-differentiated adenoma to invasive carcinoma in a transgenic mouse model of pancreatic $\beta$-cell carcinogenesis (Perl et al. 1998).

Adhesion molecules are thought to be involved in $\beta$-cell activity as well. Rapid expression of polysialylated (PSA)neural cell adhesion molecule (NCAM) at the surface of $\beta$-cells was observed under conditions that stimulate insulin secretion (Kiss et al. 1994) and differential expression of PSA-NCAM in the $\beta$-cell population correlates with differences in glucose responsiveness (Bernard-Kargar et al. 2001). In addition, blockade of E-cadherin-mediated cell adhesion in pancreatic islets abolishes glucose-stimulated increases in intracellular $\mathrm{Ca}^{2+}$ levels and insulin secretion, suggesting that loss of E-cadherin in $\beta$-cells is associated with impaired insulin secretion (Yamagata et al. 2002). Finally, expression levels of 
E-cadherin were reduced in animal models of type 2 diabetes in which the islet architecture was perturbed (Shih et al. 2002).

This work was designed to study E-cadherin in $\beta$-cells from the adult rat, in order to assess whether the expression of this molecule at the surface of $\beta$-cells is regulated by glucose and correlates with insulin secretion.

\section{Materials and Methods}

\section{Islet isolation and $\beta$-cell purification}

Islets of Langerhans were isolated by collagenase digestion of pancreases from male Sprague-Dawley rats (weighing 180-200 g), followed by Ficoll purification using a modification of previously described procedures (Sutton et al. 1986, Rouiller et al. 1990). This protocol was approved by the Geneva veterinary authorities. For cell preparation, the isolated islets were rinsed thrice with $\mathrm{Mg}^{2+}{ }_{-}, \mathrm{Ca}^{2+}$-free PBS and resuspended in $1.5 \mathrm{ml}$ of the same buffer containing $0 \cdot 016 \%$ of trypsin (activity against casein, 1:250) and 0.0066\% EDTA (Gibco, Life Technologies). Digestion (with occasional pipetting) was for $6 \mathrm{~min}$ at $37^{\circ} \mathrm{C}$ and was stopped by the addition of $10 \mathrm{ml}$ ice-cold Krebs-Ringer bicarbonate buffer, $10 \mathrm{mM}$ Hepes, $\mathrm{pH} 7 \cdot 4$ (KRB), containing $0 \cdot 5 \% \mathrm{BSA}$ and $2 \cdot 8 \mathrm{mM}$ glucose. $\beta$-Cells were then separated from non- $\beta$-cells by autofluorescence-activated sorting using a FACStar-Plus cell sorter (Becton-Dickinson, San Jose, CA, USA), as previously described (van de Winkel \& Pipeleers 1983, Rouiller et al. 1990), resulting in a population comprising 9598\% (insulin-positive) $\beta$-cells.

\section{Standard cell culture}

Sorted $\beta$-cells were washed twice in $10-15 \mathrm{ml}$ sterile Dulbecco's minimum essential medium (DMEM; Gibco, Life Technologies), containing $11.1 \mathrm{mM}$ glucose and $10 \%$ heat-inactivated fetal calf serum and supplemented with $110 \mathrm{U} / \mathrm{ml}$ penicillin, $110 \mu \mathrm{g} / \mathrm{ml}$ streptomycin, and $50 \mu \mathrm{g} / \mathrm{ml}$ gentamicin (complete DMEM). After centrifugation for $10 \mathrm{~min}$ at $130 \mathrm{~g}$, aliquots of $10^{5}$ cells were seeded in nonadherent $60 \mathrm{~mm}$ diameter Petri dishes containing $3 \mathrm{ml}$ medium. Cells were then incubated for $18-24 \mathrm{~h}$ at $37^{\circ} \mathrm{C}$ to allow full recovery of any cell surface molecules that may have been lost or damaged during islet isolation or cell purification.

\section{Immunofluorescence labeling on pancreas sections and isolated $\beta$-cells}

Samples of Sprague-Dawley rat pancreases were frozen in liquid nitrogen. Cryosections (5 mm thick) were then prepared, attached to slides, and fixed for $10 \mathrm{~min}$ at room temperature with a solution of $4 \%$ paraformaldehyde in PBS. Purified $\beta$-cells, attached in Cunningham's chambers, were rinsed with PBS and fixed or not with 4\% paraformaldehyde for $20 \mathrm{~min}$. Cryosections and fixed cells were then treated with $0 \cdot 1 \%$ Triton X-100 in PBS for $10 \mathrm{~min}$ and preincubated for $30 \mathrm{~min}$ at room temperature in PBS containing $0 \cdot 1 \%$ BSA. These preparations were exposed for $2 \mathrm{~h}$ at room temperature to a rabbit anti-E-cadherin polyclonal antibody prepared as previously described (Butz \& Kemler 1994) and diluted 1:200 in PBS containing 0.1\% BSA. After three washes in PBS, they were incubated for $1 \mathrm{~h}$ at room temperature with a fluorescein isothiocyanate (FITC)-conjugated goat antirabbit antibody (Sigma), diluted 1:100 in PBS containing 0.1\% BSA and finally washed thrice with PBS. For living (non-fixed) cells attached to Cunningham's chambers treatment with Triton $\mathrm{X}-100$ and preincubation were omitted, and both incubations with primary and secondary antibodies were performed at $4{ }^{\circ} \mathrm{C}$ for $1 \mathrm{~h}$. Cells were then fixed $20 \mathrm{~min}$ with $4 \%$ paraformaldehyde and rinsed thrice with PBS.

The specificity of the anti-E-cadherin serum has been tested i) on protein extract of insulin-expressing cells analyzed by western blotting, it recognizes a major band with apparent molecular weight of about $120 \mathrm{kDa}$, corresponding to the MW of E-cadherin (not shown); ii) on pancreas section (see Fig. 1), only epithelial tissue was labeled and staining was restricted to the cell membrane; and iii) pre-immune serum from the same animal did not stain any cell or tissue.

In some cases, paraformaldehyde-fixed cells were submitted to an immunofluorescence for insulin. To this end, cells were permeabilized with Triton X-100 $(0 \cdot 1 \%, 10 \mathrm{~min})$ and then incubated for $2 \mathrm{~h}$ with an anti-insulin guinea pig serum prepared as previously described (Wright et al. 1968), (1:600), and $1 \mathrm{~h}$ with a rhodamine-conjugated goat anti-guinea pig antibody (1:400). All preparations were examined by fluorescence microscopy (Zeiss Axiophot, Oberkochen, Germany).

To assess whether insulin and E-cadherin co-localized into the same granules, paraformaldehyde-fixed cells were first permeabilized with Triton X-100 (0.1\%, $10 \mathrm{~min})$, and then exposed to the same anti-insulin and anti-E-cadherin antibodies and secondary antibodies described above. Preparations were examined by confocal microscopy (LSM510 Meta, Zeiss).

\section{E-cadherin expression tested by FACS}

Sorted $\beta$-cells were washed twice with complete DMEM and incubated for $18 \mathrm{~h}$ at $37^{\circ} \mathrm{C}$ in complete DMEM containing either $2.8 \mathrm{mM}, 11.1 \mathrm{mM}, 22.2 \mathrm{mM}$ glucose, or $22.2 \mathrm{mM}$ glucose and $0.5 \mathrm{mM}$ isobutylmethylxanthine (IBMX); the cells were incubated at low density $\left(10^{5}\right.$ cells $\left./ 10 \mathrm{ml}\right)$ in non-adherent $10 \mathrm{~cm}$ diameter Petri dishes in order to prevent aggregation. The cells were then rinsed with cold KRB medium supplemented with $0 \cdot 1 \%$ BSA and $2 \cdot 8 \mathrm{mM}$ glucose (KRB) and incubated for $45 \mathrm{~min}$ at $4{ }^{\circ} \mathrm{C}$ with the rabbit anti-E-cadherin antibody or a non-immune rabbit serum, diluted 1:200 in KRB. The cells were then rinsed thrice with $\mathrm{KRB}$ and incubated again for $45 \mathrm{~min}$ at $4{ }^{\circ} \mathrm{C}$ with a FITC-conjugated-goat anti-rabbit antibody (Sigma), diluted 1:100 in KRB. Then, the cells were rinsed thrice with KRB and analyzed using a FACSCalibur flow cytometer (Beckton-Dickinson).

\section{Trypsin treatment and E-cadherin expression recovery test}

$\beta$-Cells purified by fluorescence-activated cell sorting (FACS) and incubated 18-24 h under standard conditions were rinsed 

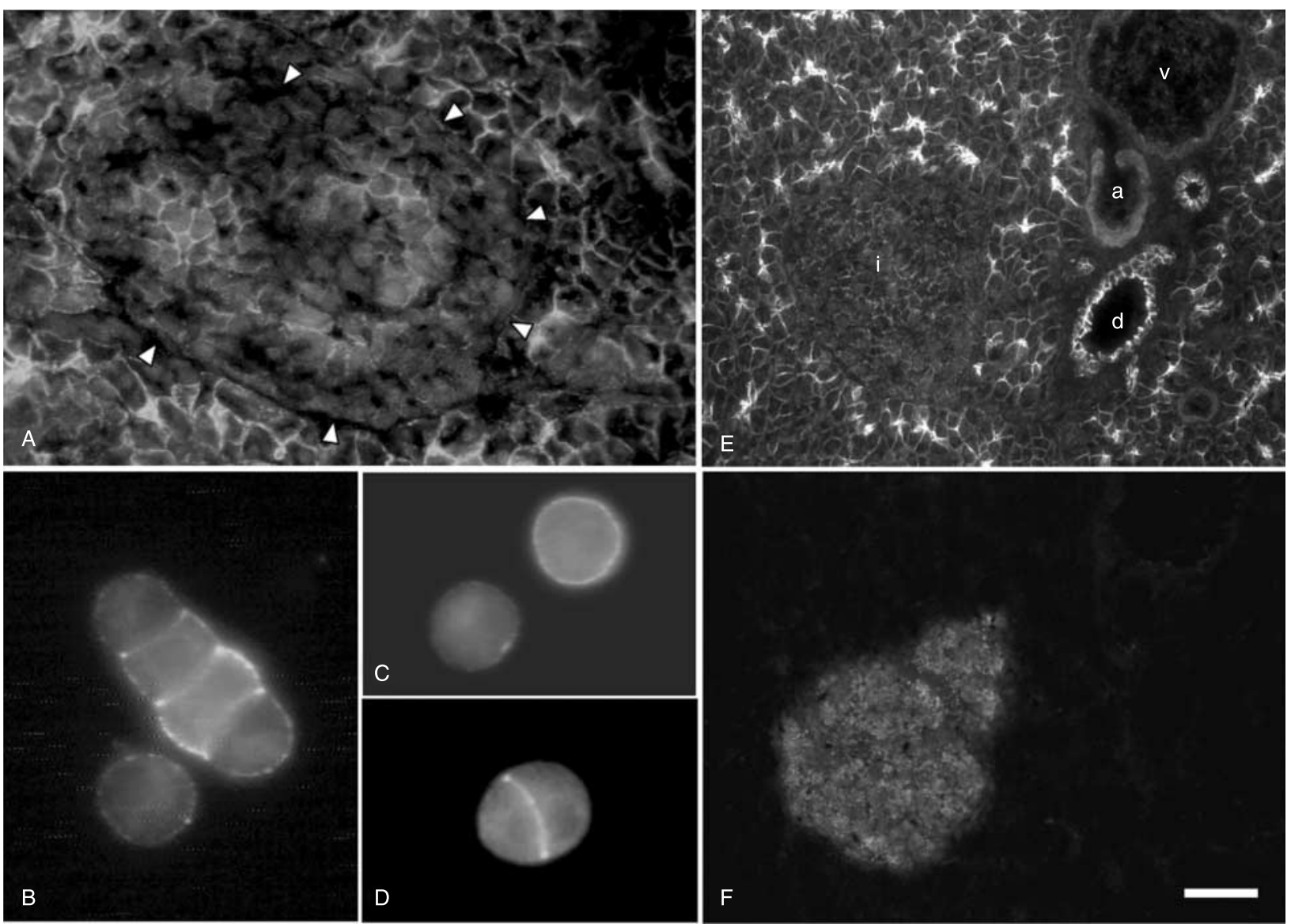

Figure 1 Heterogeneous expression of E-cadherin at the surface of $\beta$-cells. (A) Sections of rat pancreas showing labeling for E-cadherin at the cell surface in both exocrine and endocrine tissues. The islet of Langerhans, delimited by arrowheads, presents cells that are heterogeneously labeled. (B and C), Living purified $\beta$-cells labeled for E-cadherin. Coexistence of weak and strong labeling is evident in both aggregated (B) and single $\beta$-cells (C). (D), Immunostaining on a fixed and permeabilized aggregate of two $\beta$-cells showing a strong labeling at the cell-cell contact. (E and F), Section of rat pancreas co-stained for E-cadherin (green in E) and insulin (red in F); a specific cell surface labeling for E-cadherin was present in islet (i) and exocrine tissue, including pancreatic duct (d), and was absent in artery (a) and vein (v). The bar represents $40 \mu \mathrm{m}$ in $\mathrm{A}, 15 \mu \mathrm{m}$ in $\mathrm{B}, \mathrm{C}$ and $\mathrm{D}$, and $80 \mu \mathrm{m}$ in $\mathrm{E}$ and $\mathrm{F}$.

twice with PBS without $\mathrm{Ca}^{2+}$ and $\mathrm{Mg}^{2+}$ and incubated at $37^{\circ} \mathrm{C}$ for $6 \mathrm{~min}$ with the same buffer containing $0.016 \%$ of trypsin (activity against casein, 1:250) and $0.3 \mathrm{mM}$ EDTA (Gibco, Life Technologies). The cells were rinsed with complete DMEM and resuspended in the same medium containing either $2 \cdot 8$ or $16.7 \mathrm{mM}$ glucose and supplemented or not with $10 \mu \mathrm{M}$ cycloheximide, $5 \mu \mathrm{g} / \mathrm{ml}$ cytochalasin B (Sigma), or $10 \mu \mathrm{g} / \mathrm{ml}$ latrunculin B (Calbiochem, Darmstadt, Germany). Then, the cells $\left(10-15 \times 10^{3} / 50 \mu \mathrm{l}\right)$ were introduced into Cunningham's chambers, previously coated with poly-L-lysine and incubated for 1 or $3 \mathrm{~h}$ at $37^{\circ} \mathrm{C}$. E-cadherin expression was then evaluated on living cells as described below.

\section{Aggregation assay}

After purification, $\beta$-cells were incubated for $18 \mathrm{~h}$ in complete DMEM containing $2 \cdot 8 \mathrm{mM}$ glucose; the cell density was too low $\left(10^{5}\right.$ cells $/ 10 \mathrm{ml}$ in non-adherent $10 \mathrm{~cm}$ diameter Petri dishes) to prevent cell aggregation. The cells were then incubated for $45 \mathrm{~min}$ at $37^{\circ} \mathrm{C}$ in $\mathrm{KRB}$ buffer supplemented with $0.1 \%$ BSA containing either $2 \cdot 8$ or $16.7 \mathrm{mM}$ glucose. The cells were washed either with control $\mathrm{KRB}$ or with $\mathrm{Ca}^{2+}{ }_{-}, \mathrm{Mg}^{2+}$-free $\mathrm{KRB}$, supplemented with $0 \cdot 1 \%$ BSA and 2.8 or $16.7 \mathrm{mM}$ glucose. Then, the cells were submitted to an aggregation test as previously described (Rouiller et al. 1990). Briefly, cells were suspended in $150 \mu \mathrm{l}$ of the same buffers at a concentration of $5 \times$ $10^{5} / \mathrm{ml}$ in $10 \mathrm{ml}$ polycarbonate conical tubes (Nunc, Roskilden, Denmark). The tubes were then placed at a fixed angle $\left(30^{\circ}\right)$ in a shaking water bath $(80$ cycles $/ \mathrm{min})$ at $37^{\circ} \mathrm{C}$ for $60 \mathrm{~min}$. Aggregation was assessed quantitatively by comparing the number of events before and after the aggregation period as measured in a ZM Coulter counter (Coulter Electronics, Luton, $\mathrm{UK})$. The percentage of aggregation was given by the following formula: $((b-a) / b) \times 100$, where $b$ is the number of events before aggregation and $a$ is the number of events counted after the 60-min aggregation period. 
Fluorescence-activated cell sorting of $\beta$-cells with differential expression of E-cadherin on their surface

After their purification by FACS, $\beta$-cells were incubated for $24 \mathrm{~h}$ in complete DMEM, cells were cultured at low density $\left(10^{5}\right.$ cells $/ 10 \mathrm{ml}$ in $10 \mathrm{~cm}$ diameter Petri dishes) to prevent their reaggregation. Cells were then rinsed with PBS supplemented with $0 \cdot 1 \%$ BSA and incubated for $60 \mathrm{~min}$ at $4{ }^{\circ} \mathrm{C}$ with the rabbit anti-E-cadherin antibody, diluted 1:200 in PBS- $-0 \cdot 1 \%$ BSA. After three washes with PBS- $0 \cdot 1 \%$ BSA, cells were incubated again for $60 \mathrm{~min}$ at $4{ }^{\circ} \mathrm{C}$ with a FITCconjugated goat anti-rabbit antibody (Sigma), diluted 1:160 in PBS- $-0 \cdot 1 \%$ BSA. Finally, cells were rinsed thrice with PBS$0 \cdot 1 \%$ BSA and sorted using a FACStar-plus (BectonDickinson). An argon laser illuminated the cells at $488 \mathrm{~nm}$ and an interference filter detected the emission light at 510-540 nm. Forward light scatter and fluorescence channel 1 were used to analyze the cells in dot plots. Two windows were set to enclose the high-labeled and the low-labeled $\beta$-cells respectively. Sorted cells were then rinsed twice with complete DMEM and incubated in the same medium for $24 \mathrm{~h}$ before processing for reverse hemolytic plaque assay (RHPA). In one experiment, proteins were extracted with acid-ethanol from 80000 cells from each cell population and cellular insulin content was measured by ELISA.

\section{Insulin secretion by RHPA}

Insulin secretion of $\beta$-cells was assessed by a RHPA, as previously described (Salomon \& Meda 1986, Bosco \& Meda 1998). Briefly, $\beta$-cells were diluted in KRB buffer supplemented with $0 \cdot 1 \%$ BSA and $2 \cdot 8 \mathrm{mM}$ glucose. Five percent $(\mathrm{v} / \mathrm{v})$ of packed sheep red blood cells (Behring Institute, Marburg, Germany) previously coated with protein A were then mixed with $\beta$-cells, and $50-60 \mu 1$ of this preparation were introduced into Cunningham's chambers. After 1-h incubation at $37^{\circ} \mathrm{C}$, the chambers were first rinsed with KRB containing either 2.8 or $16.7 \mathrm{mM}$ glucose, and then filled with the same buffer, supplemented with a heat-inactivated $\left(45 \mathrm{~min}\right.$ at $56^{\circ} \mathrm{C}$ ) anti-insulin guinea pig serum (Wright et al. 1968), (1:50). After 1 -h incubation at $37^{\circ} \mathrm{C}$, chambers were rinsed with $\mathrm{KRB}$ containing $2 \cdot 8 \mathrm{mM}$ glucose, filled with the same buffer containing guinea pig complement (1:40, Behring Institute), and incubated at $37^{\circ} \mathrm{C}$ for $1 \mathrm{~h}$. Chambers were then filled with a $0 \cdot 04 \%(\mathrm{w} / \mathrm{v})$ solution of trypan blue in $\mathrm{KRB}$, rinsed with $\mathrm{KRB}$, and filled with $4 \%$ paraformaldehyde. Analysis was restricted to single cells that excluded trypan blue at the end of the plaque assay. Results are expressed as total plaque development, which represents the total plaque area formed by 100 cells (Bosco \& Meda 1998).

\section{Statistical analysis}

Data are presented as mean \pm s.E.M. for $n$ independent experiments, and levels of significance for differences between groups were assessed by Student's $t$-test for unpaired groups.
Where appropriate, differences were tested by ANOVA followed by a post hoc Scheffe test.

\section{Results}

Heterogeneous expression of E-cadherin at the surface of $\beta$-cells

When immunostaining of E-cadherin was performed on pancreas sections, both exocrine tissue and islets were shown to be labeled (Fig. 1A). In both instances, labeling was confined to the cell membrane and mainly localized to cellto-cell contacts. Within islets, expression of E-cadherin was rather heterogeneous, with some cells showing a strong and others a weak labeling. In many islets (19/30 from four different pancreases), the strongest labeling was on the more centrally located cells (Fig. 1A, E and F). To further assess the expression of E-cadherin in $\beta$-cells, immunostaining was performed on isolated $\beta$-cells purified by FACS. In this case too, heterogeneity was obvious (Fig. 1B and C). Single and aggregated $\beta$-cells displayed a surface staining (Fig. 1B and C) that became clearly stronger at the cell-to-cell contacts when labeling was performed on permeabilized cells (Fig. 1D). By double staining for E-cadherin and insulin, it was confirmed that low and high E-cadherin expressing cells were $\beta$-cells (Fig. 2A-C). On permeabilized cells, we observed a granular cytoplasmic labeling for E-cadherin by conventional light microscopy that could have been accounted for by background labeling. However, by confocal microscopy, it was apparent that some of these E-cadherin dots were also labeled for insulin (Fig. 2D and E). This suggests that E-cadherin and insulin can be co-localized within the same granules.

\section{Insulin secretion from $\beta$-cell subpopulations sorted according to their E-cadherin expression}

Due to the above-described heterogeneity of E-cadherin expression and to the well-known heterogeneity of insulin secretion from isolated $\beta$-cells (Salomon \& Meda 1986, Bosco et al. 1989), we wondered whether there was a correlation between E-cadherin expression and insulin secretion. To address this, $\beta$-cells were sorted according to their E-cadherin expression as illustrated in Fig. 3A. Thus, two cell subpopulations were obtained expressing low ('ECAd-low') and high ('ECad-high') levels of E-cadherin. Then, the two subpopulations were tested for their ability to secrete insulin using a RHPA. At low glucose concentration $(2 \cdot 8 \mathrm{mM})$, the total plaque development (which represents the total plaque area formed by $100 \beta$-cells) was low $\left(\sim 10 \times 10^{3} \mu \mathrm{m}^{2}\right)$ for both subpopulations. After 1-h stimulation with $16.7 \mathrm{mM}$ glucose, the total plaque development was about $100 \times 10^{3} \mu \mathrm{m}^{2}$ for the ECAd-high cells and significantly lower (about $50 \times 10^{3} \mu \mathrm{m}^{2}$ ) for the ECad-low cells (Fig. 3B). Cellular insulin content measured by ELISA on extracts from 80000 cells in a single control experiment, was $4 \cdot 5$ and $3.25 \mathrm{pg} /$ cell for ECad-low and ECAd-high cells respectively and as such if anything 

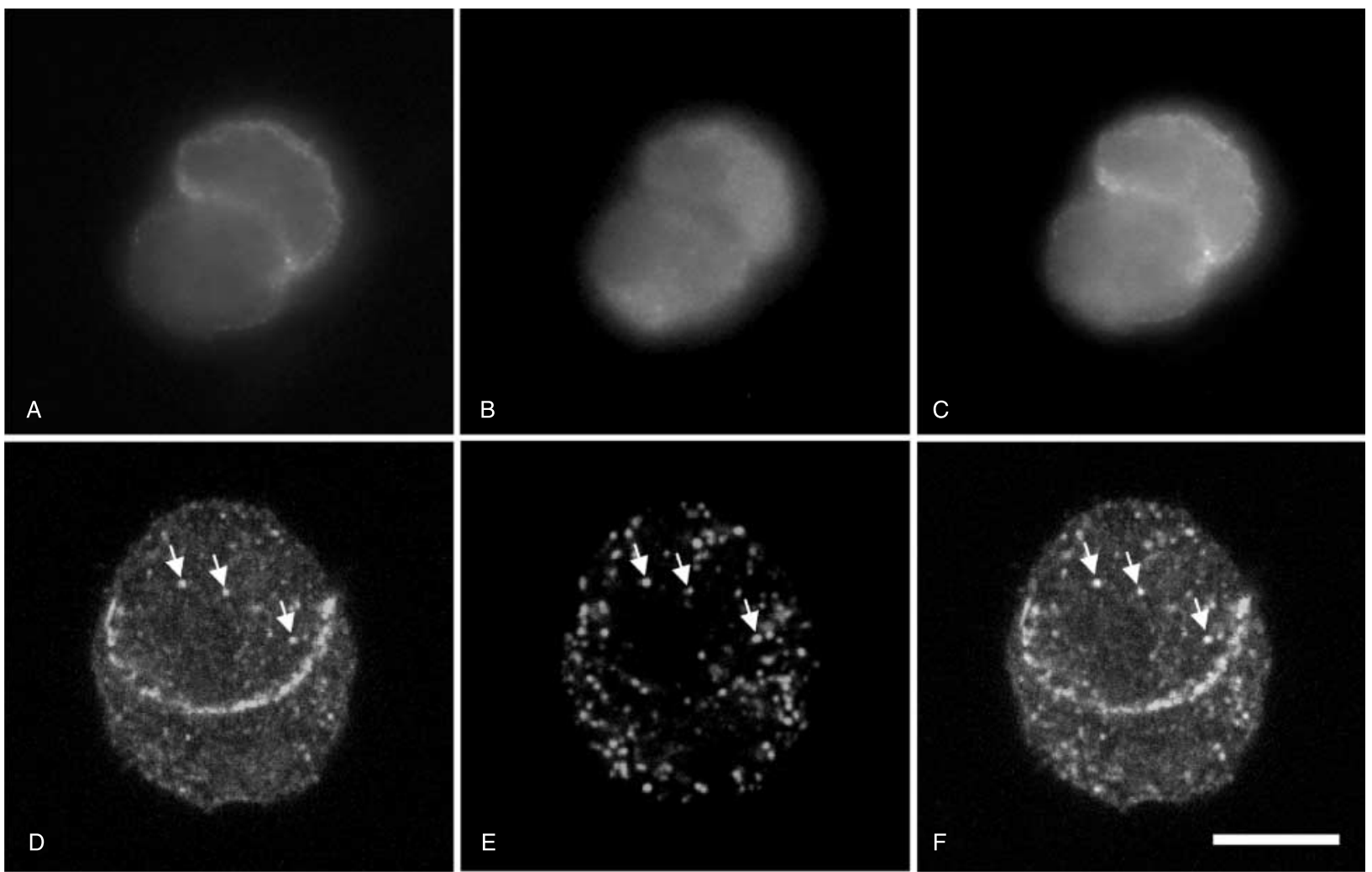

Figure 2 Colocalization of E-cadherin and insulin. (A-C) Fluorescence-microscopy views of a $\beta$-cell pair comprising one cell with a stronger membrane labeling for E-Cadherin than the other. (A) Living cells were first labeled for E-cadherin using a FITC-conjugated secondary antibody (green on original figure). (B) Then, cells were fixed, permeabilized, and labeled for insulin using a rhodamine-conjugated secondary antibody (red on original figure). (C) Merged figures. (D, E) Confocal microscopy views of a $\beta$-cell pair after fixation, permeabilization, and labeling for E-cadherin (D) and insulin (E). E-cadherin was labeled using a FITC-conjugated secondary antibody (D, green on original figure), and insulin was labeled using a rhodamine-conjugated secondary antibody (E, red on original figure). Merged figures are shown in (F). Arrows show granules that are labeled for both E-cadherin and insulin and appearing in yellow on original merged figure.

higher in the ECad-low population that secreted less insulin in response to glucose. This indicates that there is a correlation between the expression of E-cadherin at the surface of $\beta$-cells and glucose-induced insulin secretion that is not related to a corresponding change in insulin content.

\section{Effect of glucose on E-cadherin expression at the surface of $\beta$-cells}

This set of experiments was aimed to assess whether insulin secretagogues modulated E-cadherin expressed at the surface of $\beta$-cells. Isolated $\beta$-cells were incubated for $18 \mathrm{~h}$ at either low $(2.8 \mathrm{mM})$, intermediate $(11.1 \mathrm{mM})$, or high $(22.2 \mathrm{mM})$ glucose concentrations; the last condition was supplemented or not with $0.5 \mathrm{mM}$ IBMX. Then, cell surface expression of E-cadherin was analyzed by FACS after immunofluorescence performed on living $\beta$-cells. Figure 4A shows the distribution of E-cadherin fluorescence in the $\beta$-cell population incubated under these different conditions. With increasing glucose concentrations, the distribution of E-cadherin staining showed a shift toward higher fluorescence values. The presence of IBMX induced the highest shift. Quantitative results (Fig. 4B) show that the mean fluorescence value was increased by $50 \%$ for both $11 \cdot 1$ and $22 \cdot 2$ vs $2 \cdot 8 \mathrm{mM}$ glucose and by $100 \%$ for $22 \cdot 2 \mathrm{mM}$ glucose supplemented with IBMX versus $2.8 \mathrm{mM}$ glucose. These results show that insulin secretagogues (glucose and IBMX) have a positive effect on the expression of E-cadherin.

To understand better the effect of glucose on E-cadherin expression, isolated $\beta$-cells were treated with trypsin to remove membranous E-cadherin. Then, E-cadherin recovery at the cell surface was tested by immunofluorescence and microscopic analysis. Immediately after trypsin treatment, virtually no cells expressed E-cadherin (not shown). With time, the percentage of labeled cells gradually increased, and virtually all cells were found labeled after $18 \mathrm{~h}$ of culture in the presence of 2.8 or $16.7 \mathrm{mM}$ glucose (Fig. 5). After 1 and $3 \mathrm{~h}$ of incubation, the percentage of labeled cells was higher in the presence of $16.7 \mathrm{mM}$ glucose when compared with $2.8 \mathrm{mM}$ glucose. These data indicate that re-expression of E-cadherin at the surface of $\beta$-cells occurs at both low and high glucose concentrations, but is accelerated under conditions that stimulate insulin secretion $(16 \cdot 7 \mathrm{mM}$ glucose). 


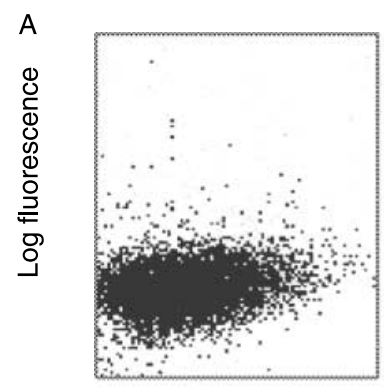

B

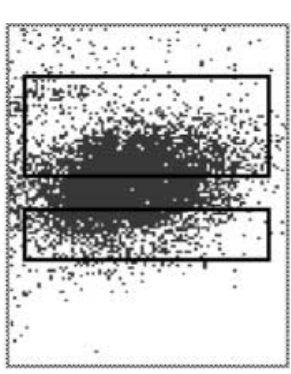

High

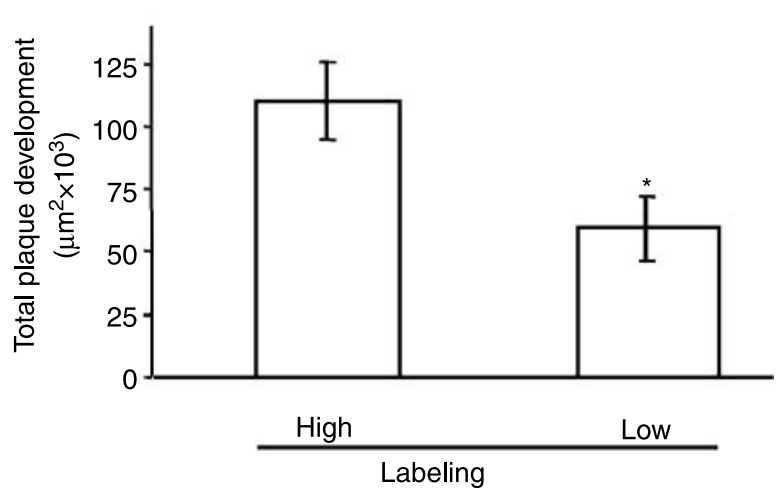

Figure 3 Insulin secretion from $\beta$-cell subpopulations sorted according to their E-cadherin expression. (A) Dot plot analysis of dissociated $\beta$-cells examined for their fluorescence and cell size. Left panel represents $\beta$-cells before and right panel $\beta$-cells after immunofluorescence labeling with an E-cadherin antibody. $\beta$-Cells presenting high and low fluorescence were sorted using the top and bottom windows respectively. (B) Insulin release from sorted $\beta$-cells with high and low E-cadherin labeling was studied using a RHPA after 1-h incubation at $16 \cdot 7 \mathrm{mM}$ glucose and expressed as total plaque development. Data are means \pm s.E.M. of four independent experiments and show that $\beta$-cells expressing high levels of E-cadherin secreted twofold more insulin than $\beta$-cell expressing low levels $\left({ }^{*} P<0 \cdot 02\right)$.

\section{Effect of glucose on $\beta$-cell aggregation}

To show that E-cadherin expressed at the $\beta$-cell membrane was functionally active, an aggregation test was performed with $\beta$-cells pre-incubated for $45 \mathrm{~min}$ (Fig. 6) at either 2.8 or $16.7 \mathrm{mM}$ glucose. When the test was run in the presence of $\mathrm{Ca}^{2+}$, aggregation of cells pre-incubated at $16.7 \mathrm{mM}$ glucose was significantly higher than that of cells pre-incubated at $2.8 \mathrm{mM}$ glucose. In absence of $\mathrm{Ca}^{2+}$, aggregation was significantly lower and no difference was observed between $2 \cdot 8$ and $16.7 \mathrm{mM}$ glucose, indicating that only cell aggregation mediated by $\mathrm{Ca}^{2+}$-dependent adhesion molecules was affected by glucose.

\section{Effect of cycloheximide on the expression of E-cadherin}

The time-dependent appearance of E-cadherin at the $\beta$-cell surface under non-stimulated conditions suggests that its expression is, at least in part, constitutive. To further verify this hypothesis and to determine whether this depended upon
A

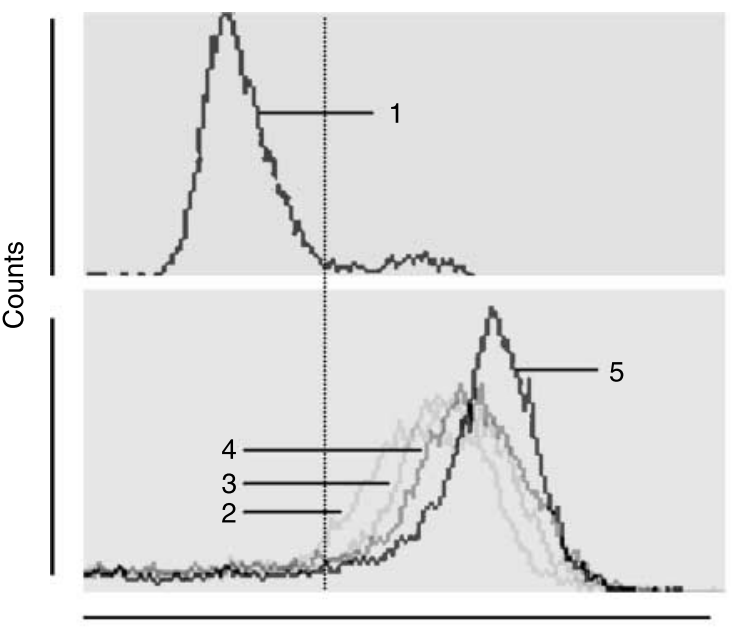

Log fluorescence

B

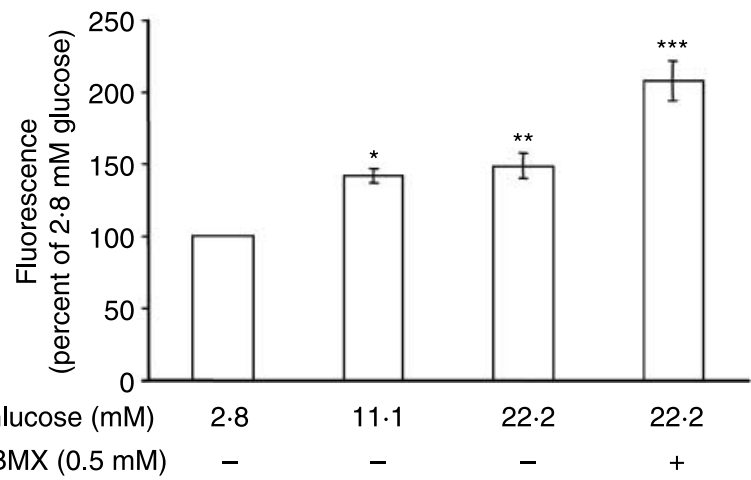

Figure 4 Effect of glucose on expression of E-cadherin at the surface of $\beta$-cells evaluated by FACS. (A) Distribution of E-cadherin fluorescence measured by flow cytometry on $\beta$-cells incubated at different glucose concentrations. Distribution 1 represents cells analyzed before immunostaining. Distributions $2-5$ represent cells analyzed after immunostaining and previously incubated in the presence of $2 \cdot 8$ (distribution 2), $11 \cdot 1$ (distribution 3 ), $22 \cdot 2 \mathrm{mM}$ glucose (distribution 4 ), and $22 \cdot 2 \mathrm{mM}$ glucose supplemented with IBMX (distribution 5) for $18 \mathrm{~h}$ (B). Quantitative results of the experiments illustrated in $(A)$. For each distribution, the mean fluorescence was calculated and expressed as the percent of the value obtained for $2 \cdot 8 \mathrm{mM}$ glucose. Data are mean \pm S.E.M. of four independent experiments. Differences were tested statistically using ANOVA and post hoc Scheffe tests. Fluorescence is significantly higher at $11 \cdot 1\left({ }^{*} P<0 \cdot 04\right)$ and $22 \cdot 2\left({ }^{* *} P<0 \cdot 02\right)$ vs $2 \cdot 8 \mathrm{mM}$ glucose and at $22 \cdot 2 \mathrm{mM}$ glucose supplemented with IBMX $(* * * P<0 \cdot 005)$ vs $2 \cdot 8,11 \cdot 1$, or $22 \cdot 2 \mathrm{mM}$ glucose alone.

synthesis of new proteins, the effect of the protein synthesis inhibitor cycloheximide was tested on the recovery of E-cadherin expression at the cell surface after trypsin treatment of $\beta$-cells. When incubated at $2 \cdot 8 \mathrm{mM}$ glucose after trypsin treatment, cycloheximide completely inhibited the time-dependent rescue of E-cadherin expression (Fig. 7). These results argue in favor of a requirement for synthesis of new molecules of E-cadherin for its re-expression at the $\beta$-cell surface under basal conditions. However, at $16.7 \mathrm{mM}$ glucose, cycloheximide did not inhibit recovery of 


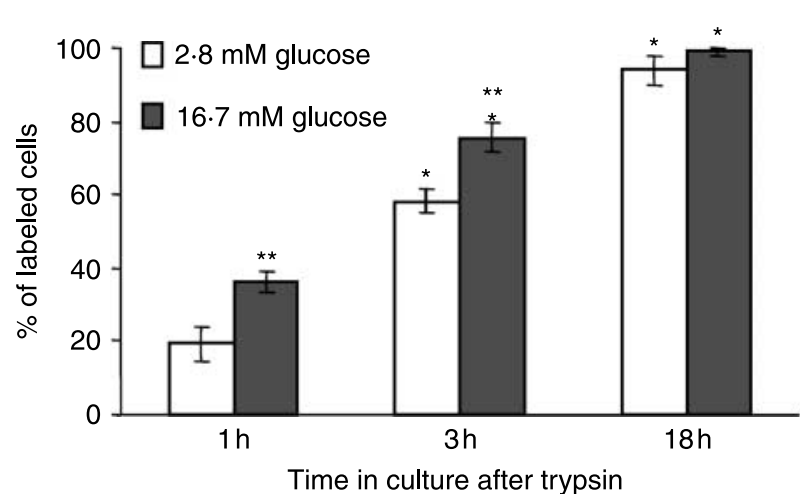

Figure 5 Effect of glucose on the expression of E-cadherin at the surface of $\beta$-cells after trypsin treatment. $\beta$-Cells were treated with trypsin and incubated for 1,3 , or $18 \mathrm{~h}$ in medium containing $2 \cdot 8$ (white columns) or $16 \cdot 7 \mathrm{mM}$ glucose (black columns). The cells were then labeled by immunofluorescence for E-cadherin and the percentage of labeled cells were determined. Data are mean \pm s.E.M. of five, six, and three independent experiments for 1,3 , and $18 \mathrm{~h}$ respectively. At both $2 \cdot 8$ and $16 \cdot 7 \mathrm{mM}$ glucose, the percentage of labeled cells significantly increased with time in culture $(* P<0 \cdot 02-$ $0 \cdot 0001)$. At 1 and $3 \mathrm{~h}$, the percentage of labeled cells was higher at 16.7 vs $2 \cdot 8 \mathrm{mM}$ glucose $\left({ }^{* *} P<0 \cdot 02-0 \cdot 01\right)$.

E-cadherin (Fig. 7). This suggests that a pool of intracellular E-cadherin may be present in $\beta$-cells and could be expressed at the cell membrane only after glucose stimulation.

\section{Effect of cytochalasin and latrunculin on the expression of E-cadherin}

Depolymerization of actin filaments lying beneath the $\beta$-cell membrane has been shown to promote exocytosis of insulin granules (Malaisse \& Orci 1979, Howell \& Tyhurst 1986). In order to assess whether depolymerization of this actin

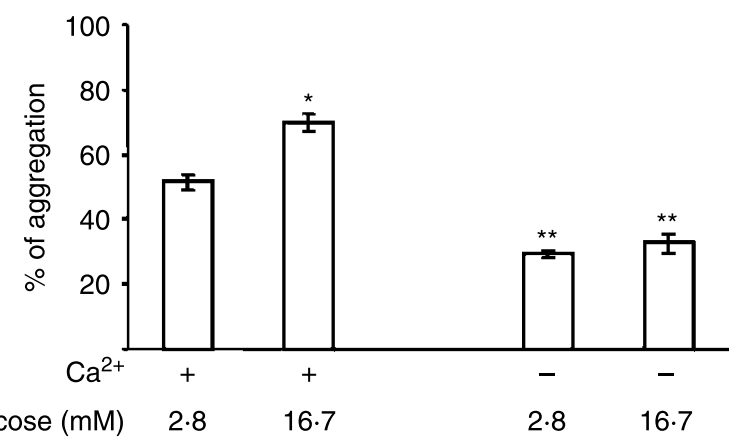

Figure 6 Effect of glucose on $\beta$-cell aggregation. $\beta$-Cells were incubated in static conditions for $18 \mathrm{~h}$ in culture medium containing $2 \cdot 8 \mathrm{mM}$ glucose; the cells were then transferred in KRB containing either 2.8 or $16 \cdot 7 \mathrm{mM}$ glucose, incubated for $45 \mathrm{~min}$ at $37^{\circ} \mathrm{C}$, and submitted to the aggregation test under the same glucose concentration and in the presence or absence of $\mathrm{Ca}^{2+}$. Data are mean \pm S.E.M. of four independent experiments; in the presence of $\mathrm{Ca}^{2+}$, aggregation was higher $(* P<0.002)$ in $16.7 \mathrm{vs} 2.8 \mathrm{mM}$ glucose; in the absence of $\mathrm{Ca}^{2+}$, aggregation was significantly diminished (**P<0*005) and no effect of glucose was observed.

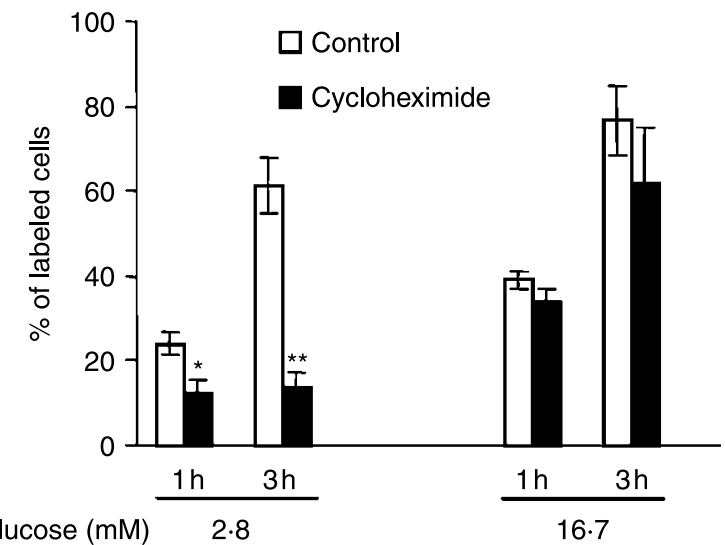

Figure 7 Effect of cycloheximide on the expression of E-cadherin at the surface of $\beta$-cells. $\beta$-Cells were treated with trypsin and incubated for 1 and $3 \mathrm{~h}$ in culture medium containing $2 \cdot 8$ or $16.7 \mathrm{mM}$ glucose, supplemented (black columns) or not (white columns) with $10 \mu \mathrm{M}$ cycloheximide. The cells were then labeled by immunofluorescence for E-cadherin and the percentage of labeled cells were determined. Data are mean \pm s.E.M. of three independent experiments. At $2 \cdot 8 \mathrm{mM}$ glucose, cycloheximide significantly decreased the percentage of labeled cells $\left({ }^{*} P<0 \cdot 04\right.$ for $1 \mathrm{~h}$, and ${ }^{* *} P<0 \cdot 005$ for $3 \mathrm{~h}$ ).

network could affect E-cadherin expression, $\beta$-cells were treated with trypsin, and recovery of E-cadherin at the cell membrane was studied in the absence or presence of drugs that depolymerize actin filaments: cytochalasin-B and latrunculin B. When trypsinized, and successively incubated for $3 \mathrm{~h}$ at $2.8 \mathrm{mM}$ glucose, $20 \%$ of $\beta$-cells expressed E-cadherin. Under this glucose concentration, the percentage significantly increased up to $40-50 \%$ in the presence of cytochalasin or latrunculin (Fig. 8). After $3 \mathrm{~h}$ at $16.7 \mathrm{mM}$ glucose, the percentage of $\beta$-cells expressing E-cadherin was

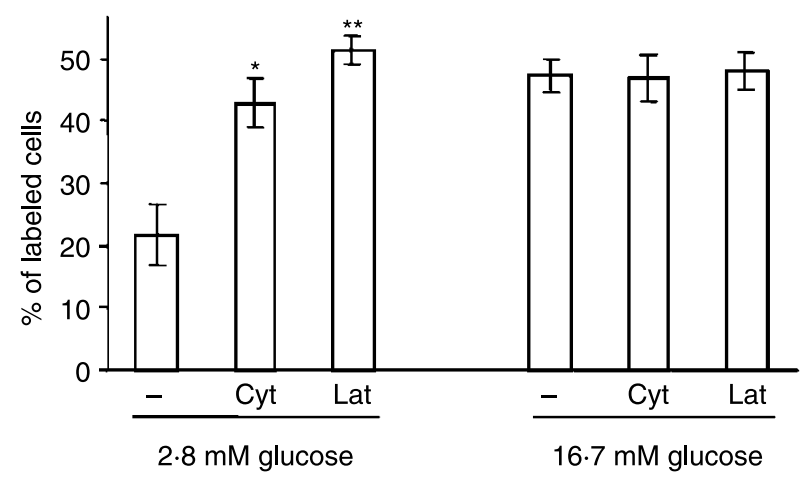

Figure 8 Effect of cytochalasin B and latrunculin on the expression of E-cadherin at the surface of $\beta$-cells. $\beta$-cells were treated with trypsin and incubated for $3 \mathrm{~h}$ in medium containing $2 \cdot 8$ or $16 \cdot 7 \mathrm{mM}$ glucose and supplemented or not with $5 \mu \mathrm{g} / \mathrm{ml}$ cytochalasin B or $10 \mu \mathrm{M}$ latrunculin $\mathrm{B}$. The cells were then labeled by immunofluorescence for E-cadherin and the percentage of labeled cells were determined. Columns are means \pm S.E.M. of three independent experiments. At $2 \cdot 8 \mathrm{mM}$ glucose, cytochalasin $B\left({ }^{*} P<0 \cdot 03\right)$ and latrunculin $\left({ }^{* *} P<0 \cdot 01\right)$ significantly increased the percentage of labeled cells versus control condition. 
already elevated in the absence of cytochalasin or latrunculin and was not further increased in the presence of these drugs (Fig. 8). These data show that even in absence of metabolic activation by glucose, it is possible to improve the expression of E-cadherin at the cell surface with drugs that depolymerize cortical actin and thereby favoring access of granules to the membrane for exocytosis.

\section{Discussion}

In this work, we show that the expression of E-cadherin at the surface of $\beta$-cells is heterogeneous, regulated by secretagogues including glucose and correlates with insulin secretory capacity from individual $\beta$-cells. We base these conclusions on several lines of evidence. Heterogeneity of surface labeling of $\beta$-cells with anti-E-Cadherin was evident in vitro on dispersed cells but also in situ on pancreas sections, suggesting that this is not an artefact of islet isolation or more specifically of the procedure for sorting $\beta$-cells by FACS. When E-cadherin was stripped from $\beta$-cells by trypsinization, the rate of reappearance of this adhesion molecule at the cell surface was quite variable, suggesting that either the rate of E-cadherin synthesis or of its recycling differs between $\beta$-cells. We attempted to distinguish between these alternatives by inhibiting protein synthesis with cycloheximide. The results of such inhibition indicated that the reappearance of E-cadherin at low glucose is entirely dependent on protein synthesis, whereas at high glucose, this dependence is only partial. It is concluded that glucose stimulates recycling of E-cadherin from an intracellular pool of previously existing protein, whereas reappearance of E-cadherin at low glucose is constitutive and dependent upon protein synthesis. Additional data are compatible with the pool recruited to the cell surface by high glucose being present on membranes of insulin secretory granules. Stimulation of insulin secretion, whether by glucose alone or the combination of high glucose and elevation of intracellular cAMP (IBMX) thus resulted in a graded increase in surface E-cadherin that correlates with the well-established stimulation of secretion by glucose with or without IBMX. A similar phenomenon has been demonstrated for another cell adhesion molecule, PSA-NCAM, that is presented at the surface of $\beta$-cells in response to secretagogues as a result of its localization to insulin granule membranes (Kiss et al. 1994).

It has been shown previously that $\beta$-cells are heterogeneous both in terms of deployment of surface proteins and insulin secretion. The amounts of both NCAM and integrins have thus been shown to differ from one $\beta$-cell to the next (Bosco et al. 2000, Bernard-Kargar et al. 2001), and functional heterogeneity has been documented by several groups (Salomon \& Meda 1986, Stefan et al. 1987, Pralong et al. 1990, Soria et al. 1991, van Schravendijk et al. 1992). In the present study, the strongest labeling of E-cadherin was observed in the more central part of islets, corresponding to $\beta$-cells that have the higher insulin secretion activity (Stefan et al. 1987). To further investigate whether a correlation does exist between E-cadherin expression and insulin secretion, we sorted by FACS a poorly labeled and a highly labeled $\beta$-cell population. By RHPA, we found that the highly E-cadherin expressing $\beta$-cells secreted more insulin than the other cells. These results are in accord with those of Bernard-Kargar et al. (2001) that showed a correlation between the abundance of PSA-NCAM expressed at the cell membrane and insulin secretion. When we measured insulin secretion by RHPA, only single $\beta$-cells were analyzed. Under these circumstances, there would be no contribution of E-cadherin signaling toward $\beta$-cell function, since this cell adhesion molecule is active only when it is engaged in $\mathrm{Ca}^{2+}$-dependent homophylic engagement of another molecule on a neighboring cell. We thus believe that cells with high levels of E-cadherin do so as a result of their high secretory capacity and not the contrary. In a previous work, using similar FACS and RHPA technologies used in this study, we demonstrated that insulin secretory activity of single $\beta$-cells correlated with their size (Giordano et al. 1993). Here, a correlation between $\beta$-cell size and E-cadherin expression cannot be excluded. FACS analysis of dissociated and E-cadherin-labeled $\beta$-cells (Fig. 3A) may suggest that highly labeled $\beta$-cells were bigger than poorly labeled $\beta$-cells. Further analyses by microscopy and morphometry are needed to confirm this.

Cell-to-cell adhesion is known to improve insulin secretion (Bosco et al. 1989). Here, we show that E-cadherin at the cell surface is functionally active. Indeed, $\beta$-cells were able to reaggregate in a calcium-dependent manner and glucose increased aggregation in a dose-dependent fashion. Our hypothesis is that glucose activates E-cadherin expression at the surface of $\beta$-cells, leading to the development of cellto-cell contacts and/or reinforcement of signaling via E-cadherin. In turn, these events could improve glucoseinduced insulin secretion. Our results further identify E-cadherin as a new surrogate cell surface marker for $\beta$-cell function that may be useful in the development of noninvasive imaging technology for clinical assessment of functional $\beta$-cell mass.

\section{Acknowledgements}

This work was supported by grant numbers 3200B0100656/1, 3200B0-101902, and 310000-113967/1 from the Swiss National Science Fund. We thank Caroline Raveraud, Nadja Perriraz-Mayer, Stephane Dupuis, and Christian Morandi for expert technical assistance. The authors declare that there is no conflict of interest that would prejudice the impartiality of this scientific work.

\section{References}

Aberle H, Schwartz H \& Kemler R 1996 Cadherin-catenin complex: protein interactions and their implications for cadherin function. Journal of Cellular Biochemistry $61514-523$. 
Angst BD, Marcozzi C \& Magee AI 2001 The cadherin superfamily: diversity in form and function. Journal of Cell Science 114 629-641.

Behrens J, von Kries JP, Kuhl M, Bruhn L, Wedlich D, Grosschedl R \& Birchmeier W 1996 Functional interaction of beta-catenin with the transcription factor LEF-1. Nature 382 638-642.

Bernard-Kargar C, Kassis N, Berthault MF, Pralong W \& Ktorza A 2001 Sialylated form of the neural cell adhesion molecule (NCAM): a new tool for the identification and sorting of beta-cell subpopulations with different functional activity. Diabetes 50 (Suppl 1) S125-S130.

Bosco D \& Meda P 1998 Assessing release of secretory products from individual cells. In Animal Cell Culture Techniques Springer Lab Manual, pp 197-216. Ed. M Clynes. New York: Springer-Verlag.

Bosco D, Orci L \& Meda P 1989 Homologous but not heterologous contact increases the insulin secretion of individual pancreatic B-cells. Experimental Cell Research 184 72-80.

Bosco D, Meda P, Halban PA \& Rouiller DG 2000 Importance of cell-matrix interactions in rat islet beta-cell secretion in vitro: role of alpha6beta1 integrin. Diabetes 49 233-243.

Butz S \& Kemler R 1994 Distinct cadherin-catenin complexes in $\mathrm{Ca}(2+)$ dependent cell-cell adhesion. FEBS Letters 355 195-200.

Dahl U, Sjodin A \& Semb H 1996 Cadherins regulate aggregation of pancreatic beta-cells in vivo. Development 122 2895-2902.

Esni F, Taljedal IB, Perl AK, Cremer H, Christofori G \& Semb H 1999 Neural cell adhesion molecule (N-CAM) is required for cell type segregation and normal ultrastructure in pancreatic islets. Journal of Cell Biology 144 325-337.

Giordano E, Cirulli V, Bosco D, Rouiller D, Halban P \& Meda P 1993 B-cell size influences glucose-stimulated insulin secretion. American Journal of Physiology 265 C358-C364.

Howell SL \& Tyhurst M 1986 The cytoskeleton and insulin secretion. Diabetes/Metabolism Reviews 2 107-123.

Kiss JZ, Wang C, Olive S, Rougon G, Lang J, Baetens D, Harry D \& Pralong WF 1994 Activity-dependent mobilization of the adhesion molecule polysialic NCAM to the cell surface of neurons and endocrine cells. EMBO Journal 13 5284-5292.

Malaisse WJ \& Orci L 1979 The role of the cytoskeleton in pancreatic B-cell function. Methods and Achievements in Experimental Pathology 9 112-136.

Ozawa M \& Kemler R 1992 Molecular organization of the uvomorulincatenin complex. Journal of Cell Biology 116 989-996.

Perl AK, Wilgenbus P, Dahl U, Semb H \& Christofori G 1998 A causal role for E-cadherin in the transition from adenoma to carcinoma. Nature 392 190-193.

Pralong WF, Bartley C \& Wollheim CB 1990 Single islet beta-cell stimulation by nutrients: relationship between pyridine nucleotides, cytosolic $\mathrm{Ca}^{2+}$ and secretion. EMBO Journal 9 53-60.
Rouiller DG, Cirulli V \& Halban PA 1990 Differences in aggregation properties and levels of the neural cell adhesion molecule (NCAM) between islet cell types. Experimental Cell Research 191 305-312.

Rouiller DG, Cirulli V \& Halban PA 1991 Uvomorulin mediates calciumdependent aggregation of islet cells, whereas calcium-independent cell adhesion molecules distinguish between islet cell types. Developmental Biology 148 233-242.

Salomon D \& Meda P 1986 Heterogeneity and contact-dependent regulation of hormone secretion by individual B cells. Experimental Cell Research 162 507-520.

Van Schravendijk CF, Kiekens R \& Pipeleers DG 1992 Pancreatic beta cell heterogeneity in glucose-induced insulin secretion. Journal of Biological Chemistry $26721344-21348$.

Shih DQ, Heimesaat M, Kuwajima S, Stein R, Wright CV \& Stoffel M 2002 Profound defects in pancreatic beta-cell function in mice with combined heterozygous mutations in Pdx-1, Hnf-1alpha, and Hnf-3beta. PNAS 99 3818-3823.

Soria B, Chanson M, Giordano E, Bosco D \& Meda P 1991 Ion channels of glucose-responsive and -unresponsive beta-cells. Diabetes 40 1069-1078.

Stefan Y, Meda P, Neufeld M \& Orci L 1987 Stimulation of insulin secretion reveals heterogeneity of pancreatic B cells in vivo. Journal of Clinical Investigation 80 175-183.

Sutton R, Peters M, McShane P, Gray DW \& Morris PJ 1986 Isolation of rat pancreatic islets by ductal injection of collagenase. Transplantation $\mathbf{4 2}$ 689-691.

van de Winkel M \& Pipeleers D 1983 Autofluorescence-activated cell sorting of pancreatic islet cells: purification of insulin-containing B-cells according to glucose-induced changes in cellular redox state. Biochemical and Biophysical Research Communications 114 835-842.

Wright PH, Makulu DR \& Posey IJ 1968 Guinea pig anti-insulin serum. Adjuvant effect of $H$. pertussis vaccine. Diabetes 17 513-516.

Yamagata K, Nammo T, Moriwaki M, Ihara A, Iizuka K, Yang Q, Satoh T, Li M, Uenaka R, Okita K et al. 2002 Overexpression of dominant-negative mutant hepatocyte nuclear fctor-1 alpha in pancreatic beta-cells causes abnormal islet architecture with decreased expression of E-cadherin, reduced beta-cell proliferation, and diabetes. Diabetes 51 114-123.

Received in final form 20 April 2007

Accepted 27 April 2007

Made available online as an Accepted Preprint

8 May 2007 